\title{
Attitudes and perceptions regarding metabolomics research on HIV and AIDS: Towards a dynamic model relating basic beliefs, technology and behaviour
}

\begin{abstract}
Authors:
Henk Jochemsen ${ }^{1}$

Honey Nonyane ${ }^{2}$

Carolus Reinecke ${ }^{3}$

Johan Zaaiman ${ }^{4}$

\section{Affiliations:}

${ }^{1}$ Sub-department

Communication, Philosophy

and Technology, Wageningen

University and Research

Centre, The Netherlands

\section{${ }^{2}$ The Independent}

Communications Authority of

South Africa, Johannesburg,

South Africa
\end{abstract}

${ }^{3}$ Centre for Human

Metabonomics, North-West

University, Potchefstroom

Campus, South Africa

${ }^{4}$ School of Social and Government Studies,

North-West University,

Potchefstroom Campus,

South Africa

\section{Correspondence to:}

Henk Jochemsen

Email:

henk.jochemsen@wur.nl

Postal address:

PO Box 8130, Wageningen

6700 EW, The Netherlands

Dates:

Received: 21 Dec. 2012

Accepted: 02 Oct. 2013

Published: 24 July 2014

How to cite this article: Jochemsen, $\mathrm{H}$., Nonyane, H., Reinecke, C. \& Zaaiman, J., 2014, 'Attitudes and perceptions regarding metabolomics research on HIV and AIDS: Towards a dynamic model relating basic beliefs, technology and behaviour', Koers - Bulletin for Christian Scholarship 79(1), Art. \#544, 9 pages. http://dx.doi.org/10.4102/ koers.v79i1.544

Read online:

Scan this QR code with your smart phone or mobile device to read online.
The human immunodeficiency virus (HIV) and acquired immunodeficiency syndrome (AIDS) pandemic are hitting hard in Africa, not the least in South Africa. In addition to preventative measures, better ways of treatment and delaying the onset of symptoms are still urgently required. Recent developments in biomedicine in South Africa, notably genomics and metabolomics, could well contribute to more effective treatments and diets. However, these technologies are rooted in modern Western culture and may embody concepts and values that are foreign to people with a different culture and worldview in semi-urban communities in South Africa. How can those technologies be introduced into such communities in an ethically acceptable and effective way? To begin answering this question, we conducted qualitative research amongst representatives of such a community near Potchefstroom, South Africa. The results indicate that the worldview, belief system and cultural customs of these people significantly influence the interpretation of HIV and AIDS and their treatment. The results led us to expand an earlier theoretical version of a qualitative model relating cultural factors and worldview to individual behaviour into an empirically informed, dynamic model that envisages possible influences of the introduction of new technologies on the belief and behavioural system of the community.

Houdings en persepsies aangaande metabolomika-navorsing oor MIV en VIGS: Die ontwikkeling van'n dinamiese model betreffende basiese oortuigings, tegnologie en gedrag. Afrika is swaar getref deur die impak van die menslike immuuntekort-virus (MIV) en die verkreë immuungebrek-sindroom (VIGS) pandemie. Suid-Afrika is nie hierop 'n uitsondering nie. Afgesien van voorkomende maatreëls, is beter maniere van behandeling en ' $n$ vertraging in die aanvang van simptome steeds hoog op die ranglys. Resente biomediese ontwikkelinge in Suid-Afrika, spesifiek ten opsigte van genomika en metabolomika, kan wesentlik bydra tot meer doelmatige behandeling en diëte. Die aard van hierdie tegnologieë is egter gevestig in die hedendaagse Westerse kultuur en sluit konsepte en waardes in wat vreemd mag wees aan persone met ' $n$ ander kultuur en werklikheidsvisie in gemeenskappe van semi-stedelike gebiede in Suid-Afrika. Die vraag is hoe hierdie gemeenskappe op 'n eties verantwoordbare en doelmatige wyse aan hierdie tegnologieë bekendgestel kan word. Om hierdie vraag te probeer beantwoord, is ' $n$ kwalitatiewe navorsingsprojek met verteenwoordigende individue vanuit so 'n gemeenskap van Potchefstroom in Suid-Afrika onderneem. Die resultate toon dat die wêreldbeeld en oortuigings van hierdie groep betekenisvol bydra tot hulle beskouing van MIV en VIGS en die behandeling daarvan. Deur hierdie gegewens kon 'n bestaande kwalitatiewe en teoretiese model, wat kulturele en wêreldbeskoulike oortuigings met die oriëntasie van individue in verband bring, uitgebrei word in 'n empiries geïnformeerde dinamiese model wat die effek van die invoer van nuwe tegnologieë op die oortuigings en gedragsisteem van die gemeenskap uitbeeld.

\section{Introduction}

\section{Scientific background}

It is widely recognised that the 'HIV [human immunodeficiency virus] epidemic remains an unprecedented human catastrophe inflicting immense suffering on countries, communities and families throughout the world' (UNAIDS 2011). In South Africa, it was noted that, in 2009, approximately 5.7 million people were living with HIV and AIDS (UNAIDS 2010:180). Research on preventative and therapeutic interventions remains crucial.

Both biomedical and life style approaches to the search for new treatments of HIV and AIDS could benefit from at least two of the contemporary 'omics' technologies: genomics and metabolomics. 
Genomics is concerned with the study of the genomes of organisms. Metabolomics entails the investigation of the metabolome of organisms, which represents the collection of the low molecular weight metabolites of the biochemical processes in a cell, tissue, organ or organism. Metabolomics has been shown to be a new and promising approach to the study of inherited metabolic (Reinecke et al. 2012) and infectious pathological disorders (Parida \& Kaufmann 2010). Metabolomics and genomics research on HIV and AIDS would be aimed at the development of new techniques for early diagnosis and therapeutic interventions, for example through a healthy diet, nutritional supplements or other applicable approaches, including monitoring of treatment (Fawzi et al. 2004). Such research can contribute to defining a strategy for personalised medicine (Van der Greef, Hankemeyer \& McBurney 2006), amongst others for those suffering from serious conditions such as HIV infection.

However, the application of the fundamental genomics and metabolomics research in clinical practice would require clinical research involving human subjects from whom samples of bio-fluids such as blood saliva or urine should be obtained, as well as detailed personal and clinical information from the participants. Such investigations with human subjects raise several concerns about ethical and scientific issues, especially in dealing with communities with wide disparities in education, economic and social standing, as well as diversities in national policies and practices in health care and human rights systems (Glickman et al. 2009).

\section{Problem statement}

Genomics and metabolomics research form part of a scientific approach of the human body and of disease that is characteristic of modern Western culture, whereas many communities in large parts of the world, for example in South Africa, live in a culture in which completely different views of the human being, health and disease prevail (Jochemsen \& Reinecke 2011). How could the introduction of such new modern techniques and their implicit views influence the understanding of health and disease, self-perception and social relations?

In our view, the application of metabolomics research on HIV faces at least two critical issues related to the attitudes and perceptions of the people supposed to benefit from such research, including semi-rural black communities. Firstly, many people in South Africa are reluctant to have themselves tested for HIV and to give consent to the gathering of information and sampling required for this category of investigations (Mills 2006; Pretorius, Goldstein \& Stuart 2005; Williams et al. 2012). Research amongst certain populations thus clearly underscores the importance of participants' perceptions for the possible benefits of research and projected interventions (Corbie-Smith et al. 1999; Garber et al. 2007). An important question, therefore, is this: How can it be communicated to prospective participants that the research really intends to benefit them, thereby furthering their participation?
Secondly, the introduction of new modern technologies will provide information to the participants about their genetic vulnerability to the development of AIDS after HIV infection, as the genetic predisposition of responders and nonresponders to HIV infection and therapy is well established (Piconi et al. 2011). Such personal insights could negatively affect the individuals' self-perception and their social position, for example through a process of stigmatisation (Gordon et al. 2005:1047; Michie, Bobrow \& Marteau 2001:519; Stempsey 2006).

Against this background, it is imperative that possible genomics and metabolomics investigations into HIV are carried out in a way that embodies the ethical obligation to prevent possible deleterious experiences and social consequences of such research and its results. How can this be done?

This article seeks to attain insight into possible ways of applying advanced biomedical techniques in semi-urban black communities in an effective and ethically sound way.

\section{Theoretical framework}

The problem statement refers to possible effects of modern biomedical research amongst semi-rural communities whose culture differs from modern Western culture, from which such research originated. Carrying out such biomedical research in an ethically responsible way requires insight into and knowledge of the attitudes towards and perceptions of such research and its possible impact amongst the targeted populations.

The investigation of those attitudes and perceptions requires at least the beginning of a model of the relationships between personal and socio-cultural factors and communal and individual behaviour. Such a theoretical model was developed from philosophical and natural science perspectives (Jochemsen \& Reinecke 2011) and improved with interaction in a multi-disciplinary group of participants at a conference on Philosophy, Technology and Society (Maarssen, the Netherlands 2010), as well as through anonymous peer reviews. The model is outlined in Figure 1, on the next page.

The model in Figure 1 was adopted by the authors since they adhere to some of its implicit philosophical views, especially with respect to the view of humankind. The human being is considered to be religious, relational and responsible. The first attribute pertains to the idea that human beings invariably understand themselves in relation to what they consider to be 'unconditionally non-dependent reality' (Clouser 2005); for many people, this is their religious belief. In this view, behaviour is, in some way, always influenced by the person's religious and worldview beliefs that inform their perception and understanding of reality and make sense of life. This behaviour also concerns the acceptance of new techniques and the adoption of scientific models as correct representations of reality (Clouser 2005; Van der Walt 2001:43-62). The human being is considered to be a relational being, meaning that 


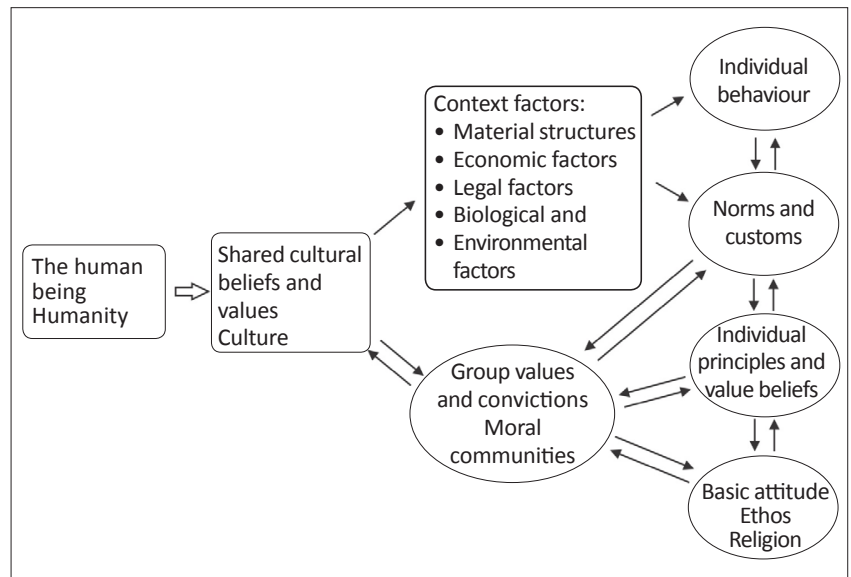

Note: This model indicates that, behind individual human behaviour (the circle on the righ at the top of the figure), different motivational layers can be distinguished. The reaction of a person to a new phenomenon stems from a number of theoretically distinguishable layers of beliefs regarding norms and values and regarding the basic character of reality and of the source of beliefs and meaning (religion). In this model, religion is viewed in functional anthropological sense, namely as the manifestation of the relationship to what is considered ultimate reality (Clouser 2005. Gove 1971). Such beliefs and 'ultimate concern' considered ultimate reality (Clouser 2005, Gove 1971). Such beliefs and 'ultimate concerns' in mortent contex and culture and (see Jochemsen \& Reinecke 2011 for a detailed discussion of this model).

FIGURE 1: A model of external and internal influences on individual behaviour.

life is lived in communities, not just as a precondition for survival, but as a necessary context for becoming human and flourishing as a human. Thirdly, in our view, human beings are responsible. Although individual human life and behaviour is influenced and shaped to a large extent by the community and its culture and customs, these do not fully determine the individual's life. People, created in the image of God, have an undeniable responsibility for their own life and for their close relations and their community at large. History shows that, time and again, people have been able to break through the conventions of their community and deal with situations considered to be unjust or undesirable. The social research reported in this article starts from the presupposition that people's behaviour, both in established customs and in actions that challenge those customs, is influenced by their fundamental beliefs and their spiritual and moral attitudes, and sees this confirmed in the results.

The investigation reported in this article was informed by the model of Figure 1 in the sense that this model helped to formulate the kind of questions we had to ask in order to get the type of answers we sought. The model should not be read in a deterministic way as if the factors indicated in the model fully determine the behaviour of each individual of a certain community. Circumstances do differ and are valued differently by different people, and values are also generally shared in the community. Hence, this research does not aim to predict individual behaviour but to understand the kinds of factors and motives that influence the behaviour of people from a certain community.

\section{Empirical research Qualitative research}

Since our investigation aimed at obtaining an in-depth understanding of human attitudes and behaviour regarding new biomedical research and the reasons that govern such behaviour, we decided to use qualitative social scientific methods (Kvale 1996; 2007). Such qualitative research gives information on the different views and attitudes amongst the participants, but not on their statistical distribution of opinions in the population represented by them. The chosen qualitative research method was the semi-structured, indepth interview of individuals because an interview can uncover information, most importantly, at a meaning level (Turner 2010). The standardised, open-ended interview approach was followed by using an interview guide with a number of questions indicating the topics in which we wanted to ascertain the participants' views. ${ }^{1}$ Participants were asked the same, mainly open, questions, which allowed them to contribute as much detailed information as they desired whilst also allowing the investigator to ask additional probing questions as a means of follow-up (Gall, Gall \& Borg 2003).

\section{Interviewers' training}

Interviewers need to know how to conduct the interviews based on the semi-structured guide and with a reflective approach to the knowledge sought. Moreover, they should have a clear background of the study and why the study is important. Thus, to enable the interviewer to control the validity of the results, she completed the prescribed course in research methodology as part of the degree curriculum, had an in-depth orientation to the scope of metabolomics investigation by the Centre for Human Metabonomics at North-West University (South Africa) and followed an accredited certificate course on HIV and AIDS and how to approach individuals living with HIV or AIDS.

\section{Selection of research participants and data collection}

The purpose of qualitative research interviews is to understand the subjects' point of view and to uncover the meaning of their experiences. In general, 7-10 interviews are sufficient for satisfactory data generation in qualitative research investigating responses to straightforward questions amongst a homogenous group. However, since this research concerned the sensitive and complex issues of HIV and AIDS and genetics, in which the participants' views would possibly widely differ, a convenience sample of 12 individuals was interviewed.

The first contact with the participants took place at the Top City Clinic in Ikageng through the intermediation of the manager, who confidentially asked possible participants whether they were willing to participate. HIV-negative participants were selected from the people who came in for voluntary counselling and testing (VCT) on the days the interviewer was at the clinic. Before giving their consent to being introduced to the interviewer, the post-testing negative participants were informed by the manager what the study entailed. As a result of the selection, interviewees represented a diversity of involvement with HIV and AIDS. Amongst 1.The guideline for the interviews can be obtained from the first author of this article. 
the participants were HIV-positive and HIV-negative individuals, a community leader, nurses, counsellors and traditional healers from a clinic in the black township of Ikageng in Potchefstroom, South Africa. Some participants were interviewed in a private room at a health clinic, others in their homes. The interviews generally took one hour each.

Since the language used in the interviews may influence the outcome of the research (Peltzer et al. 2008), during the interview, the open questions that were written in English were translated by the interviewer into Setswana and Sesotho for those who were not fluent in English.

To enhance the quality of the data collection, the interviews were recorded (by tape recorder and subsequently transcribed) to ensure precise recollection of data and to provide the researcher with an objective document with which to analyse the gathered information.

\section{Analysis}

The texts of the interviews were analysed according to standard methods of qualitative text analysis (Creswell 2007). In brief, the manuscript was fragmented into meaning units that were condensed and coded with themes; themes with related content were organised under categories (a group of content that shares a commonality). The categories with the content received from the collective interviews provided the content to answer the research questions. Measures taken to guarantee the reliability and validity of the research included a trial interview, debriefing between interviews with two other authors (Henk Jochemsen \& Johan Zaaiman) on the basis of the research journal, and researcher and data triangulation (Graneheim \& Lundman 2004).

In the process of the interpretation of the data, we first tried to obtain an understanding of the different factors that influenced the attitudes and perceptions of the target group regarding their possible involvement in genomics and metabolomics research. In addition, we related the observations to the model (Figure 1) that informed the questions with the intention of validating and possibly revising the model. Although a validation or a revision of the model was not a direct goal of this research, the results could possibly be used also to realise that.

\section{Ethical approval}

This investigation formed part of the post-graduate projects within the School of Social Sciences of the North-West University and complied with the ethical requirements set for such projects. Informed consent forms were signed by all of the participants, and they also agreed to the recording of the interviews. The data were reported anonymously. The researcher also obtained permission from the manager of the clinic (who served there as a nurse) to interview HIV-positive people.

\section{Results}

This section provides results obtained from the interviews with respect to the participants' general attitudes and perspectives on health issues and, more specifically, on HIV and AIDS and heredity and genetic predisposition. These results are structured according to the main topics of the interview guide.

\section{Health issues}

The answers dealing with health focused on consulting traditional healers, healthy food and blood donation. The participants indicated that, when faced with health problems, they would consult a medical doctor (4 participants), a clinic (4 participants), a traditional healer (3 participants), a church (2 participants) or ancestors ( 2 participants). Clearly, for the participants, science-based medicine was just one option to seek healing. In any case, the majority of the participants had no problem with the use of needles. One participant stated, 'I don't have a problem with it but, because of the many diseases, I like to make sure that the needle is safe.' The two traditional healers rejected the use of needles as the needles were considered as being dangerous. Most participants were not afraid of the sight of blood. A few indicated that they were afraid of the blood of other people because of the possibility of infections.

To the question about what cultural values or customs with respect to health were maintained in their community, the responses varied from traditional healing (6 responses), ancestors (4 responses), curses, and witchcraft, to God and spiritual powers. In general, the participants held a positive view of traditional healers. Ten participants indicated that they play an important and positive role, 3 participants pointed out the role of traditional leaders in giving training with regard to HIV and AIDS, but a few participants indicated they would not personally consult a traditional healer, partly due to their churches' teaching. The medical doctor had a negative view of their role and said, 'The role that I have seen them play is that people first go to them and, by the time they get to the hospital, they are about to die.'

\section{HIV and AIDS}

With respect to people's perceptions of HIV and AIDS, it was found that the level of knowledge was still low, even though most of them (7 participants) knew that it was mostly a sexually transmitted disease. The finding that most participants indicated condom use or abstinence or faithfulness as protection against HIV confirms this. For instance, one participant said, 'By staying away from sex if you are not married'. However, more detailed knowledge about HIV was limited. Only a few participants knew that HIV could be transmitted by sharing needles, by accidents in medical care, and by mother-to-child transition during birth. Virtually all the participants knew people who had died of AIDS.

Two healthcare professionals asserted that HIV-positive people should start taking antiretroviral (ART) drugs. The 
traditional healers' view differed from established medical opinion; one mentioned curses as a cause of HIV and the other that AIDS was a consequence of having sex with a widow who was not cleansed after her husband's death. To them, the ritual of cleansing the woman would be the best prevention.

Some participants and the traditional healers viewed traditional healers as the best fighters of AIDS. This appeared to have a cultural background. One participant answered to the question of whom he would consult about health issues: 'Traditional healers, because this thing is mostly amongst black people, and we know our people'. Somebody else stated, 'Traditional healers, especially amongst black people; white people do not know black medicine'. Others opted for medical doctors as the best AIDS fighters, '.. because they came up with ARTs, whereas traditional healers have not come up with anything'.

The view that traditional healers and medical doctors should collaborate was widespread amongst the participants, if only for strategic reasons: 'Because it is obvious that our people consult with them [traditional healers]'. However, the traditional healers and the medical doctor did not favour collaboration, although one traditional healer would do so conditionally: 'But there shouldn't be others who are superior to others'.

All the participants considered that their cultural traditions did not allow the use of condoms, but half of them rejected their tradition in this respect: 'Condoms are Western things, and it changes our tradition, and we use them as we get urbanised'. Others wanted to uphold tradition: 'Our tradition does not stand for adultery so, if you respect that part of tradition, you should not have a problem with condom use and tradition'.

It is generally understood that consistent use of condoms protects against HIV and AIDS. People found condoms easily accessible (at clinics, pubs or public toilets), also for young people. Some participants remarked: 'You even find young children playing with them as balloons'. However, feelings of shame as well as cultural customs might prevent them from actually getting the condoms (Pithey \& Morojele 2002). A participant said:

'... it is very difficult for a grown man like me to go and fetch a condom while people are looking. ... I think that something should be done to create easy access'.

It was generally known that confidential HIV tests are possible at a clinic or at VCT mobiles. A majority of the participants (9 participants) had had an HIV test, some of them because of feeling ill.

\section{Perceptions of HIV and AIDS research}

Only 4 participants had participated in some HIV research, some in the form of an interview. Only one participant (out of the 12 interviewed) had participated in research that required taking a blood sample.
The ideas about their community's willingness to donate blood samples for research differed; some thought only half of the people would participate whereas others opined that most would do so because they were desperate for a cure for AIDS. It was also mentioned that some people might not donate blood because of their fear of witchcraft. However, some argued that a good explanation of the procedure and the research goal were important requirements for requesting blood samples. Almost all of the participants, in principle, would be willing to donate blood for research, although some had some reservations: 'Yes, but I do not want to be a guinea pig'.

Participants indicated a preference for black, female or elderly people to inform them about their HIV (status). Most important was that it would be done with respect and professionalism. All but one participant said they would be willing to disclose their HIV status for research purposes under circumstances of confidentiality and a professional context.

All the participants considered more research on HIV and AIDS necessary; some thought that the presentation of research sometimes gave false hope. One traditional healer wanted 'his profession' to be involved.

Most of the participants thought it was not necessary or even ethical to reimburse research participants for their participation, but some opined that remuneration would enhance the participation, especially of poor people.

\section{Perception of genetics}

Since the study of genomics/metabolomics pertains to genetic dispositions, we were also interested in the perceptions and opinions of the target population with respect to genetic disorders and dispositions.

The participants reported knowing about the following 'genetic' diseases or disorders: haemophilia, diabetes, albinism, hypertension, cancer, HIV, schizophrenia, and Down syndrome. It is noteworthy that some of these disorders (hypertension, HIV susceptibility) are only slightly genetically determined or, only in particular cases (cancers), genetically determined.

The majority of the participants knew of relatives with a genetic disorder. They opined that, in their community, many people would relate genetic disorders to witchcraft (5 participants), curses (4 participants) or ancestors (3 participants). Most of the participants mentioned the people's culture as reason for these responses. A lack of education and not being acquainted with the clinics in the community were also mentioned. Examples of responses are: 'Our culture teaches us that if we do not give to our ancestors, they will punish us with a curse' and:

'... if you listen to the symptoms of how they [their ancestors] were like before they died, you find out that it is a genetic disease that has been passed on to you'. 
Five participants did not know what causes genetic disorders. Others gave reasons of natural and biological factors, culture and spirits. The participants stated that they were interested in information on genetic diseases in their family. They also reported an interest in knowing about their vulnerability to AIDS once infected with HIV. As one said, 'I think it would be better if we all knew'.

\section{Discussion}

\section{Orientation}

1. This research was conducted to give general insight into the social and ethical conditions for a justifiable implementation of an extensive genomics/metabolomics research project amongst specific South African populations. The main results of the interviews were presented in the previous section. This discussion interprets and discusses the way in which insights obtained from this research can inform the implementation of such genomics/metabolomics research.

2. This discussion was primarily structured according to the main themes (categories) that surfaced during the analysis and interpretation of the interviews (see section 3). These categories are: religion and culture, medicine (modern and traditional), sexual relations, family and context (race, gender, respect, education or information). However, from the answers of the interviewees, some of these themes appear to be closely related. Therefore, they are discussed under the following headings: religion, culture and medicine; sexual relations; family and gender; race; information and education.

\section{Religion, culture and medicine}

From the interviews arises the picture that the community finds itself in a culturally and religiously ambivalent situation. On the one hand, the influence of the traditional religious beliefs and customs is still strong. On the other hand, the people are becoming more acquainted with modern medicine through its clinics and physicians. Some people prefer clinical procedures in healing, others spiritual healing, namely, healing by traditional healers who work from a spiritual interpretation of disease, whilst yet others prefer a combination of clinical and spiritual healing. In our view, a tension exists between the Christian faith and trust in traditional spiritual healers as these invoke other spirits. However, a major part of the population seems to combine different religious traditions. Spiritual healing is related to interventions with regard to ancestors, spiritual powers and being cleansed, a process mediated by traditional healers through ancestors.

Many black South Africans value and trust the values and opinions of traditional healers and strongly believe that certain diseases can be healed only by traditional healers (Mulaudzi 2005:324). Further, 'approximately 80\% of black patients visit traditional healers before or after they consult a biomedical doctor' (Abdool Karim, Ziqubu-Page \& Arendse 1994:1; Kalichman \& Simbayi 2004). For this reason Peltzer,
Mngqundaniso \& Petros (2006) have argued that traditional healers could play an important role in the prevention and treatment of HIV and AIDS. The consultation of traditional healers is also important, since tradition and traditional healers do not support condom use, a widely accepted measure of protection against HIV infection. On the other hand, some researchers argue that the traditional religious customs such as widow inheritance and virginity inspection, initiation schools, premarital counselling and sexual cleansing have their own protective effects (Mulaudzi 2005:323). This latter view is, however, debated in the literature (Albertyn 2000). The involvement of traditional healers should include some training on HIV and AIDS and agreement about their role in the provision of healthcare as a whole. For instance, keeping to diets and using herbs can play a role in the resistance against AIDS (The Dr. Rath Health Foundation 2012). One traditional healer reported that traditional healers cannot cure AIDS but that, like the biomedical professional, they could also boost the immune system (Pasi 2007:4). However, some natural scientists have discovered dangers connected to the use of traditional medicine on HIV-positive people (Govender et al. 2006).

Our results indicate that, amongst traditional healers, there is some openness toward considering a role for them in HIV and AIDS care, but they want to be treated equally with other healthcare workers. The Traditional Health Practitioners Act allows traditional healers to treat patients for HIV and AIDS and recognises them as doctors in a traditional sense so that the government can give them the rights that medical doctors have (Republic of South Africa 2008). Therefore, for the involvement of traditional healers in dealing with HIV and AIDS, relationships of trust and respect should be built. At the same time, their possible role and contribution should be made clear. They should not reject the contribution of modern medicine. If they are permitted a role in the national health care system, their willingness to accept the contribution of modern medicine could increase. It is important for them to understand that metabolomic research, for example, can be beneficial for people so that they do not counsel against participation.

With respect to genetic disorders, it seems that (some) people in the target population hold traditional beliefs about the causal role of ancestors. This means that research on genetic influences on the vulnerability for AIDS should be communicated in a way that enables people to adopt certain new insights without disturbing (too rashly) their own religious and cultural beliefs.

We believe that from a healthcare point of view it is wise to involve traditional healers in HIV and AIDS care. But it would be desirable if they were to concentrate on diagnosis and lifestyle advice and refer clients to clinics. The issue of spiritual healing is too complex to deal with here; it clearly presents a challenge to churches. ${ }^{2}$

2.The question whether a modern medical view can, in the longer run, be combined with a more 'spiritual' view regarding the effects of ancestors and curses - as orthodox Christians see the hand of God in the workings of medical drugs whilst at the same time acknowledging the biological explanation - is very interesting from the point of view of religious studies, but is beyond the scope of this article. 


\section{Sexual relations}

It is clear from the findings that young people do have sex, and research shows that the infection rate of HIV is relatively high amongst young people. As one participant said, 'Since our children are having sex at a young age, I would say 16 and upwards', when asked about the kind of people who would be willing to participate in research on HIV and AIDS. People seem to have easy access to condoms, even from a young age (Onyancha \& Ocholla 2006; UNAIDS 2012). On the other hand, shame and cultural customs might hinder people from actually getting them. Considering the easy access to protective measures, the occurrence of new infections seems to indicate that (young) people do not (always) actually get them or do not (correctly) use those measures.

\section{Family and gender}

The study shows that HIV is viewed by some participants as a female disease. For example, the traditional healers both said, 'HIV or AIDS is a sexually transmitted curse, called 'Seshwagadi' which you get when you sleep with a woman who has not been cleansed after her husband's death'. When asked about traditional community values, another participant also mentioned this curse, adding that the woman needed cleansing and not the man. This opinion demonstrates that gender plays an important role in decision-making in the (traditional) family; the man has almost absolute authority, also in matters of sexuality such as condom use (Varga 1997:47).

This and the previous subsection underline the need for helping (young) people to acquire life skills that, with respect to sexuality, go beyond explaining how to use a condom, but focuses on relationality, gender equality, mutual respect and responsibility.

\section{Race}

With regard to race, firstly, it is evident that some participants perceived the (modern) medical practice as being practised only by white doctors, whereas traditional healers are always black people. Five participants thought traditional healers were the best fighters of HIV and AIDS, especially amongst black people. Secondly, some voiced distrust towards black medical doctors '... who use one needle for more than one person to economise'. Some expressed a sense of inferiority in relation to white people, saying that people will only give blood for HIV and AIDS research '... if they see that white people are involved ...'. Good role models in the form of black physicians could help overcome such prejudices.

\section{Information and education}

Participants, in general, know what HIV and AIDS entails, but a small number of them hold ideas deviating from those generally accepted. In contrast, only a small number of the participants know the modern medical concept of genetic diseases. To ensure the successful implementation of genomics/metabolomics research, it will be necessary to explain to the participants the underlying understanding of HIV and AIDS and genetics as well as the basic ideas behind such research. In general, people have a positive perception of research on HIV and AIDS, reporting to be willing to donate blood for such research. However, people do want to be taken seriously and know in what investigation they are asked to participate.

\section{An expanded model}

In an attempt to put the results of our research into a wider interpretative framework, we correlated the data with the model presented in Figure 1. This model elucidates the relationships between cultural and personal factors, including one's belief or worldview, and behaviour. It indicates the normal functioning of the behavioural system in the context of a static community and culture. This model was used to inform the research questions for the interviews. We now address the question whether the results of our research give reason to modify that model.

The research reported in this article implies the introduction of an intervention from outside - a new technology that entails a novel way of dealing with a disease. Before introducing genomics/metabolomics research, the anticipated reaction of individuals to the intervention stemming from a different cultural or value system must be taken into account.

This is indicated in Figure 2, an expanded version of the model shown in Figure 1. The intervention embodies concepts and values from the culture from which it stems. Those concepts and values may, initially, not be clearly understood by those who will make use of that technology. However, when individuals within the community start making use of the technology for reasons of perceived personal benefit, a change of behaviour is constituted that will gradually begin

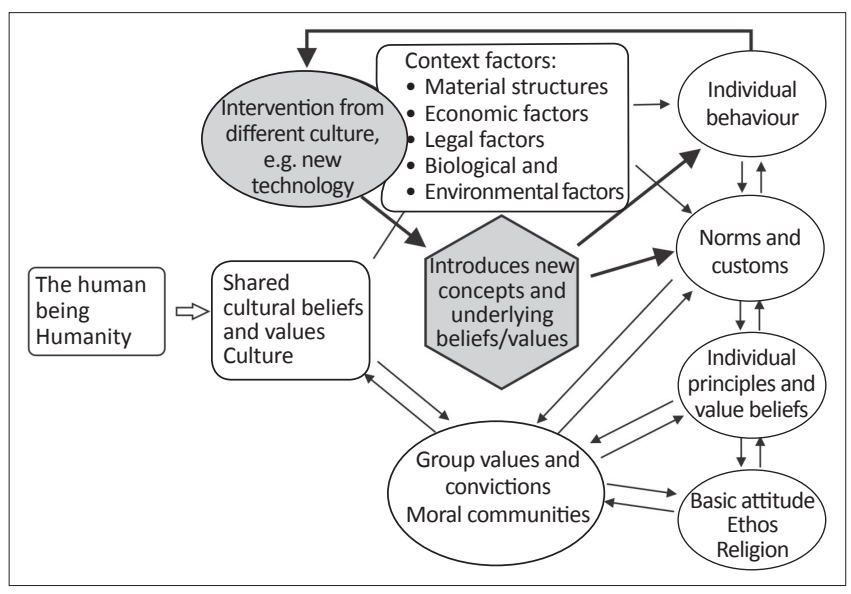

Note: This figure presents an expanded version of Figure 1 (see Figure 1). A new diagnostic or treatment technology implies the introduction of a novelty into the socio-cultural system of people (circle left, linked to the upper square). This novelty will be the carrier of new concepts and underlying values of the culture and worldview from which the technology stems (the hexagon in the centre). These concepts and implicit values may lead to a change in behaviour of individuals and directly or indirectly contribute to a change in their custom and their individual or communal value system (bold line in the right part of the figure and bold arrows between the circles on the right). At the same time, the behavioural change, as anticipated on the basis of the research presented in this article, should influence the way in which the new technology is introduced to the community (bold line from top right to intervention sphere).

FIGURE 2: Expanded model of influences on individual behaviour. 
to modify the norms and customs of the community and, in the long run, also their underlying views and values (the influence from the upper circle at the right-hand side of the figure down to the lower circles). Through those individuals, the existing socio-cultural system will be influenced (the feedback arrow from individual behaviour to the 'shared cultural beliefs and values'). For example, a knowledge of modern medical opinion on HIV and AIDS and the use of VCT will contribute to a shift in ideas about the cause of the disease: not so much a curse from someone else but a (biological) consequence of certain events or actions.

From the expanded model of influences on individual behaviour, it is clear that the introduction of new research such as that on metabolomics in a community should be preceded by an inquiry into the individual behaviour system as indicated in the original model. In the first place, insight is needed into how to present the new technology in a way that will, at least, convince a number of individuals to make use of it (cf. Airhihenbuwa \& Obregon 2000). In the second place, it should be understood how to inform and counsel individuals from the target population in such a way that they can handle the intervention and the embodied concepts and values in a way that prevents a deleterious disturbance of the socio-cultural system.

We see that this expanded model clearly illustrates the rationale behind this qualitative research and provides a better interpretative framework than the first model for the introduction of new technologies into a community to which it is alien.

\section{Concluding remarks}

This article contributes to research in connection with HIV and AIDS by studying attitudes and perceptions towards the genomics and metabolomics of HIV and genetic disorders in a specific black community and interprets the results in the light of a model relating culture and worldview to concrete behaviour. In this process of interpretation, we expanded an earlier model of this kind into a more dynamic model. The analysis of the attitudes and perceptions of people towards new ways of investigating and treating HIV and AIDS indicated that the introduction of such new and unfamiliar interventions should be done in the context of peoples' behaviour and belief system. Only by respecting and working with that system can metabolomics research be accepted and become an important role player in addressing the HIV and AIDS pandemic. At the same time, the integration of traditional healers into the healthcare system positions the churches for serious challenges.

\section{Acknowledgements Competing interests}

The authors declare that they have no financial or personal relationship(s) that may have inappropriately influenced them in writing this article.

\section{Authors' contributions}

H.J. (Wageningen University and Research Centre) proposed the design of the research and the research question; he was the second overseer and contributor to the empirical research; he was also the major author of this manuscript. H.N. (The Independent Communications Authority of South Africa) prepared and organised the interviews and carried out the interviews; she was the first investigator doing the analyses of the interview texts and used the information for her BA Honours project in Sociology. C.R. (NorthWest University) contributed to the design of the research, provided the information on the genomics and metabolomics research, instructed the interviewer in this respect, contributed to the interpretation of the results and wrote the parts of the manuscript on metabolomics. J.Z. (North-West University) contributed to the design of the research and acted as supervisor for H.N.; he was the first overseer of the empirical research; he also contributed to the interpretation and presentation of the results and to the production of the manuscript.

\section{References}

Abdool Karim, S.S., Ziqubu-Page, T.T., Arendse, R., 1994, 'Bridging the gap: Potential for health care partnership between African healers and biomedical personnel in South Africa', South African Medical Journal 84(2), 2-16.

Airhihenbuwa, C.O. \& Obregon, R., 2000, 'A critical assessment of theories/models used in health communication for HIV/AIDS', Journal of Health Communication 5 (suppl.), 5-15. http://dx.doi.org/10.1080/10810730050019528

Albertyn, C., 2000, 'Using the rights and the law to reduce women's vulnerability to HIV/AIDS', HIV AIDS Policy Law Review 5(4), 72-79.

Clouser, R.A., 2005, The myth of religious neutrality, rev. edn., University of Notre Dame Press, Notre Dame.

Corbie-Smith, G., Thomas, S.B., Williams, M.V. \& Moody-Ayers, S., 1999, 'Attitudes and beliefs of African Americans toward participation in medical research', Journal of General Internal Medicine 14, 537-546. http://dx.doi.org/10.1046/j.15251497.1999.07048.x

Creswell, C.J., 2007, Designing and conducting mixed methods research, Sage Publications, Thousand Oaks.

Fawzi, W.W., Msamanga, G.I., Spiegelman, D., Wei, R., Kapiga, S., Villamor, E. et al., 2004, 'A randomized trial of multivitamin supplements and HIV disease progression and mortality', New England Journal of Medicine 351(1), 23-32. http://dx.doi.org/10.1056/NEJMoa040541

Gall, M.D., Gall, J.P. \& Borg, W.R., 2003, Educational research: An introduction, 7th edn., A \& B Publications, Boston.

Garber, M., Hanusa, B.H., Switzer, G.E., Mellors, J. \& Arnold, R.M., 2007, 'HIV-infected African Americans are willing to participate in HIV treatment trials', Journal of General Internal Medicine 22(1), 17-42. http://dx.doi.org/10.1007/s11606-0070121-8

Glickman, S.W., McHutchison, J.G., Peterson, E.D., Cairns, C.B., Harrington, R.A., Califf, R.M. et al., 2009, 'Ethical and scientific implications of the globalization of clinical research', New England Journal of Medicine 360, 816-823. http://dx.doi. org/10.1056/NEJMsb0803929

Gordon, E.S., Gordish-Dressman, H.A., Devaney, J., Clarkson, P., Thompson, P., Gordon, P. et al. 2005, 'Nondisease genetic testing: Reporting of muscle SNPs shows effects on self-concept and health orientation scales', European Journal of Human Genetics 13, 1047-1054. http://dx.doi.org/10.1038/sj.ejhg.5201449

Gove, P.B., 1971, Webster's third new international dictionary, G. \& C. Merriam Co., Springfield.

Govender, S., Du Plessis-Stoman, D., Dowing, T.C. \& Van de Venter, M., 2006, 'Traditional herbal medicines: Microbial contamination, consumer safety and the need for standards', South African Journal of Science 102, 253-255.

Graneheim, U.H. \& Lundman, B., 2004, 'Qualitative content analysis in nursing research: Concepts, procedures and measures to achieve trustworthiness', Nurse Education Today 24, 105-112.

Jochemsen, H. \& Reinecke, C., 2011, 'Contextualizing biomedical practices in a traditional cultural setting: A discussion on three models', in J. van der Stoep \& S. Strijbos (eds.), From technology transfer to intercultural development: A disclosive vision of technology for a globalizing world, Rozenberg Publishers, Amsterdam.

Kalichman, S.C. \& Simbayi, L., 2004, 'Traditional beliefs about the cause of AIDS and AIDS-related stigma in South Africa', AIDS Care 16(5), 572-580. http://dx.doi.org/ 10.1080/09540120410001716360

Kvale, S., 1996, Interviews: An introduction to qualitative research interviewing, Sage Publications, Thousand Oaks. 
Kvale, S., 2007, Doing interviews, Sage Publications, Thousand Oaks.

Michie, S., Bobrow, M. \& Marteau, T.M., 2001, 'Predictive testing in children and adults: A study of emotional impact', Journal of Medical Genetics 38, 519-526. http://dx.doi.org/10.1136/jmg.38.8.519

Mills, B.A., 2006, 'Lonmin plc sustainable development report'. (Unpublished)

Mulaudzi, F.M., 2005, 'Attitudes, beliefs and practices of the Vhavenda in sexually transmitted diseases', Indilinga, African Journal of Indigenous Knowledge System 4(1), 323-339.

Onyancha, O.B. \& Ocholla, D.N., 2006, 'HIV/AIDS research and the youth: An infometric analysis of the literature: Research article', South African Journal of Libraries and Information Science 72(2), 85-97.

Parida, S. \& Kaufmann, S., 2010, 'The quest for biomarkers in tuberculosis', Drug Discovery Today 15, 148-157. http://dx.doi.org/10.1016/j.drudis.2009.10.005

Pasi, T.R., 2007, 'Traditional healers also have an impact on HIV: SA Media - The University of the Free State, Daily Dispatch, 10 July, p. 4.

Peltzer, K., Friend-Du Preex, N., Ramlagan, S. \& Fomundam, H., 2008, 'Use of traditional complementary and alternative medicine for HIV patients in KwaZulu-Natal, South Africa', BMC Public Health 8, 255-269. http://dx.doi.org/10.1186/1471-2458-8 255

Peltzer, K., Mngqundaniso, K. \& Petros, G., 2006, 'HIV/AIDS/STI/TB knowledge, beliefs and practices of traditional healers in KwaZulu-Natal, South Africa', AIDS Care and practices of traditional healers in KwaZulu-Natal, South A
$18(6), 608-613$. http://dx.doi.org/10.1080/09540120500294206

Piconi, S., Parisotto, S., Rizzardinil, G., Passerinil, S., Terzil, R., Argenteril, B. et al., 2011, 'Hydroxychloroquine drastically reduces immune activation in HIV-infected, art-treated, immunological non-responders', Blood 118(12), 3263-3272. http:// dx.doi.org/10.1182/blood-2011-01-329060

Pithey, A.L. \& Morojele, N.K., 2002, 'Literature review on alcohol use and sexual risk behaviour in South Africa', in sahealthinfo.org, viewed 06 August 2012, from http://www.sahealthinfo.org/admodule/review.pdf

Pretorius, H.G., Goldstein, N. \& Stuart, A.D., 2005, 'Meaning-making of a group of South Africans in their experience of living with HIV: A phenomenological study', Health SA Gesondheid 10(1), 41-51. http://dx.doi.org/10.4102/hsag.v10i1.187
Reinecke, C.J., Koekemoer, G., Van der Westhuizen, F.H., Louw, R., Lindeque, Z., Mienie, L.J. et al., 2012, 'Metabolomics of urinary organic acids in respiratory chain deficiencies in children', Metabolomics 8, 264-283. http://dx.doi.org/10.1007/ deficiencies in child

Republic of South Africa, 2008, Government gazette 511 (No. 30660), viewed 23 July 2012, from http://www.info.gov.za/view/

Stempsey, W.E., 2006, 'The geneticization of diagnostics', Medicine, Health Care and Philosophy 9, 193-200. http://dx.doi.org/10.1007/s11019-005-5292-7

The Dr. Rath Health Foundation, 2012, Results of a nutrient community health program in people affected by AIDS in South Africa, viewed 26 July 2012, from http:// www4.drrathfoundation.org/nat_vit/index.html

Turner, D.W., 2010, 'Qualitative interview design: A practical guide for novice investigators', The Qualitative Report 15, 754-760.

UNAIDS, 2010, Joint United Nations programme on HIV and AIDS: 2010 report on the global AIDS epidemic, viewed 22 February 2014, from http://www.unaids.org/ globalreport/documents/20101123_GlobalReport_full_en.pdf

UNAIDS, 2011, Political declaration on HIV and AIDS: Intensifying our efforts to eliminate HIV and AIDS (Resolution 65/277), United Nations.

UNAIDS, 2012, Fact sheet, viewed 23 July 2012, from http://www.unaids.org/ en/media/unaids/contentassets/documents/factsheet/2012/20120417 FS adolescentsyoungpeoplehiv_en.pdf

Van der Greef, J., Hankemeyer, T. \& McBurney, R.N., 2006, 'Metabolomics-based systems biology and personalized medicine: Moving towards $n=1$ clinical trials?', Pharmacogenomics 7, 1087-1094. http://dx.doi.org/10.2217/14622416.7.7.1087

Van der Walt, B.J., 2001, Transformed by the renewing of your mind, Institute of Contemporary Christianity in Africa, Potchefstroom.

Varga, C.A., 1997, 'Sexual decision-making and negotiation in the midst of AIDS: Youth in KwaZulu-Natal, South Africa', Health Transition Reviews 7, 45-67.

Williams, A., Koekemoer, G., Lindeque, Z., Reinecke, C.J. \& Meyer, D., 2012, 'Qualitative serum organic acid profiles of HIV-infected individuals not on antiretroviral treatment', Metabolomics 8, 808-818. http://dx.doi.org/10.1007/s11306-011 0376-2 